\title{
Liquidity Measurement Problems in Mining Companies
}

Agata SIERPIŃSKA-SAWICZ)

\author{
1) Uniwersytet Ekonomiczny w Poznaniu; Katedra Controllingu, Analizy Finansowej i Wyceny \\ http://doi.org/10.29227/IM-2021-01-14 \\ Submission date: 20-01-2021 | Review date: 24-05-2021
}

\begin{abstract}
The ability to manage liquidity is important in any economic conditions. It assumes unique importance during a downturn and depends on management having reliable information on the company's liquidity level. Static liquidity ratios do not provide such reliable information. Their high values result from high inventory levels of extracted raw materials and is not tantamount to excess liquidity. Additional information is offered by the cash cycle and its constituents - Days Inventory Outstanding, Accounts Receivable Days and Accounts Payable Days. Long cash cycles signal a shorter deferral of settlement of suppliers' bills and a lower liquidity level. To maintain liquidity, companies must maintain higher cash balances in their accounts. Short cycles, on the other hand, may result from late payment of invoices, which is reflected in long Accounts Payable Days. Some coal companies have very long Accounts Payable Days and negative cash conversion cycles. This means that some of their non-current assets are financed out of current liabilities.
\end{abstract}

Keywords: liquidity, liquidity ratios, cash cycle

\section{Introduction}

Company's ability to maintain liquidity is a basic precondition for ensuring continuity of its operations. Business entities that have lost liquidity tend to collapse more often than those that generate losses from time to time. If the entity is not able to meet its obligations in a timely manner, this disturbs the broader financial equilibrium and contributes to the emergence of payment gridlock. Loss of liquidity means that the company has lost its ability to pay maturing current liabilities on time because of its inability to cover operating and financial expenses out of the revenues generated during the current period or out of previously accumulated funds. Companies' experiences during the crisis in 2020 produced stronger interest on the part of managers and the state in methods ensuring liquidity and reducing the risk of running a business. Rational decisions underpinning liquidity management are a prerequisite for companies' survival and development. However, they must be based on reliable information and correct liquidity measurement.

The paper aims to show liquidity measurement problems in coal companies resulting from the specificity of their operating activities. The analysis aims at verifying the hypothesis that the level of static liquidity ratios is determined by industry specificity and does not correctly reflect the company's liquidity.

\section{The Essence of Liquidity}

Authors define the concept of liquidity in various ways and give it a multidimensional meaning. Liquidity can be viewed in terms of assets, capital and assets and cash flow. The first aspect focuses on the ease with which the company can convert its assets into cash at the shortest possible notice and without any or with only a minor loss of value (Wędzki 2003, p. 33). The capital and assets aspect expresses the company's ability to settle its current liabilities within the prescribed period (Sierpińska, Jachna 2009, p. 79). On the other hand, the cash flow aspect indicates that the company maintains liquidity if the expenses needed to cover amounts due can be settled in a timely manner from current cash inflows. Liquidity is the company's ability to generate cash flows that allow it to meet its maturing current liabilities and cover unexpected cash expenses. Wędzki (2003, p. 33) points out two basic aspects of liquidity: the purpose of money spending and the source of its origin. Unexpected expenses may be associated with the purchase of raw materials and goods at bargain prices, the need to pay fines or higher than expected financial costs caused by an increase in interest rates.

Liquidity must not be confused with solvency. In the broad sense of the word, liquidity means the ability to settle current liabilities on time, while solvency is the ability to cover total debts out of the assets held. Solvency is sometimes defined as long-term liquidity (Sierpińska and Jachna 2009, p. 145). D. Wędzki distinguishes two types of solvency: shortterm and long-term. He argues that short-term solvency is the possession by the company of assets which can be easily tuned into cash and reserves of cash and securities, whereas longterm solvency is defined as the long-term surplus of the company's assets over the liabilities used to finance them. There is no unanimity in foreign literature in respect of the concept of solvency. D. E. Kieso and J. J. Weygandt (1992, p. 209) define solvency as the company's ability to pay its debts when they are due. In turn, C. J. Bond [1993, p. 492] does not define solvency, explaining the term "insolvent" instead. A debtor is insolvent when its total debt exceeds its total assets.

To maintain liquidity, the company sometimes runs into periodic excess liquidity. Excess liquidity means that the company holds funds that it is not able to use effectively. Keeping financial surpluses in the current account contributes to a decline in management efficiency because the interest accrued on such accounts is close to zero (Kwiecień, 2015, p. 41). Lack of liquidity and excess liquidity may both undermine profitability, market position and even lead to bankruptcy. To pre- 
vent this, the owners of the entity should maintain control over current and future liquidity levels, control cash flows and take appropriate steps to ensure financial equilibrium.

\section{Liquidity Measurement}

The concept of liquidity is inextricably linked with the methods of its measurement. The company's liquidity can be measured and assessed by looking at the state of current assets and current liabilities as of the financial statements date or cash flows generated by the company in the analysed period. Hence, pertinent literature presents static methods of liquidity measurement based on balance sheet data and dynamic ones based on cash flows. Liquidity metrics based on financial flows show what funds the company had at its disposal in a given period, what was their source of origin and how they were employed. In liquidity management, special importance is attached to cash flows from operating activities.

To measure liquidity statically, use is made of the current ratio, the quick ratio and the short-term investment ratio. The current ratio is the ratio of current assets to current liabilities. This ratio makes it possible to establish whether the assets from which the company will realise cash within one balance year will suffice to settle the liabilities due within the balance sheet year. Pertinent literature recommends varying values for this ratio. According to M. Sierpińska, T. Jachna (2009, p. 147), the ratio should range between 1.2-2.0, while W. Rogowski, M. Lipski (2014, p. 13) place it between 1.5-2.0 and J. Ostaszewski and T. Cicirko (2006, p. 182) narrow the range to 1.6-1.9.

The quick ratio shows the company's ability to cover current liabilities out of the sum of receivables realisable within 12 months and short-term investments. Pertinent literature puts the ratio in the range of 1.0-1.2 (Sierpińska, Jachna 2009, p. 147). Some authors argue that a rational level is 1.0 , others range it between 0.9-1.0 (Ostaszewski, Cicirko 2006, p. 183). The short-term investment ratio is the ratio of shortterm investments to current liabilities. Pertinent literature puts the ratio should within the range of $0.1-02$, which means that short-term investments should suffice to cover 10 to $20 \%$ of current liabilities. P. Szczepaniak (2014, p. 175) puts it at $0.2-0.3$. The value of the figure depends largely on the financial strategy pursued by the management board. Both a shortage and excess of short-term investments are detrimental to the company and adversely affect its financial results.

If the calculated liquidity ratio falls short of the standard value, the company is believed to be likely to have difficulties with timely settlement of current liabilities. Contrariwise, when the value of the liquidity ratio is higher than the standard, it is assumed that there is excess liquidity. Such a normative approach to liquidity measurement is highly debatable. The value of the liquidity ratios is influenced by numerous factors beyond the management board's control and further reflects the specificity of the industry, economic situation, inflation and interest rates.

The assessment of the company's liquidity is the subject of extensive analyses, both domestically and abroad (Ashraf 2012, pp. 21-45), (Kirkham 2012, pp. 1-13), (Gowthami 2012, pp. 45-60). Pertinent literature concerned with the subject of economic and financial analysis features studies on the differ- ences between the ratios and these are explicated by means of various liquidity determining factors. For example, research into the impact of company size on liquidity conducted by $\mathrm{D}$. Zawadzka (2009) and G. Michalski (2005, pp. 55-65) shows that as the company grows, its liquidity ratios (both current and quick) mostly tend to decrease.

Liquidity assessment based on ratios of the level of current assets or their selected elements and current liabilities is not sufficient to unequivocally establish whether a decrease or increase in liquidity ratios reflects the company's actual liquidity. To calculate liquidity ratios use is made of the current assets and current liabilities as of the period for which the financial statements were compiled. In this way however, only the historical values of these assets and liabilities are included in the account. Static financial liquidity ratios disregard the time needed to convert current assets into cash, or the time specificity when current liabilities are being settled. The ratios measure the coverage of the company's future liabilities with the assets it has at its disposal during the current period. Moreover, the level of liquidity ratios may be the result of various manipulations, especially when they are used to assess management's performance.

To gain a reliable picture of the company's financial standing, the static liquidity assessment should be supplemented with additional liquidity metrics, which can partially eliminate these errors. A comprehensive approach to liquidity necessitates analysis of the duration of the cash cycle. This cycle is the sum of the Days Receivable and Days Inventory Outstanding less Days Payables Outstanding. Relevant literature states that determining the Days Payable Outstanding, shortterm debt on account of loans and borrowings and the issue of short-term debt securities should be disregarded, and only ad-hoc short-term debt should be included in the calculation. Regarding the cash cycle, the lower its value, the faster the company realises cash for the products it sold. A high value of the cash cycle implies that the company takes longer to realise cash and, consequently, the ratio may indicate liquidity problems. The longer the cash cycle, the more working capital the company must tie up to finance operating activities. This may lead to an increase in the average cost of capital and restrain the company's development. The average cost of capital may turn out to exceed the rate of return on investment that the company intends to make. Low liquidity ratios are associated with low cash cycles.

\section{Liquidity Determinants}

To determine the causes of changes in liquidity levels, the analyst should have a good understanding of liquidity determinants. These determinants can be systematised using various criteria. Pertinent literature most often mentions the extent criterion whereby the factors affecting liquidity can be divided into (Grabowska 2012, p. 20):

- microeconomic - the company's market position, pricing strategies, forms of settlements with suppliers, trade credit rules, management of net working capital, volatility of cash flows, implementation of investment projects exceeding a reasonably justifiable level, irregularities in current financial decisions. Microeconomic factors depend on the actions of individual economic entities. 
Tab. 1. Current and quick liquidity ratios in mining companies pursuing diversified activities, 2015-2019. Source: own calculations based on Ratios Key Metrics retrieved from a Reuters database

Tab. 1.Wskaźniki bieżącej i przyspieszonej płynności finansowej w spółkach wydobywczych o zdywersyfikowanej działalności w latach 2015 -2019. Źródło: opracowanie własne na podstawie Ratios - Key Metrics zaczerpniętych z bazy Reuters

\begin{tabular}{|l|l|r|r|r|r|r|}
\hline Company & Ratio & $\mathbf{2 0 1 5}$ & $\mathbf{2 0 1 6}$ & $\mathbf{2 0 1 7}$ & $\mathbf{2 0 1 8}$ & $\mathbf{2 0 1 9}$ \\
\hline \multirow{2}{*}{ Anglo American PLC } & Current Ratio & 2.36 & 1.91 & 1.99 & 1.95 & 1.92 \\
\cline { 2 - 7 } & Quick Ratio & 1.66 & 1.34 & 1.38 & 1.29 & 1.24 \\
\hline \multirow{2}{*}{ BHP Group PLC } & Current Ratio & 1.14 & 1.85 & 2.51 & 1.89 & 1.62 \\
\cline { 2 - 7 } & Quick Ratio & 1.16 & 1.53 & 2.24 & 1.58 & 1.33 \\
\hline \multirow{2}{*}{ Mechel PAO } & Current Ratio & 0.11 & 0.13 & 0.14 & 0.15 & 0.16 \\
\cline { 2 - 7 } & Quick Ratio & 0.05 & 0.06 & 0.06 & 0.06 & 0.06 \\
\hline \multirow{2}{*}{ Rio Tinto PLC } & Current Ratio & 1.52 & 1.61 & 1.66 & 1.91 & 1.56 \\
\cline { 2 - 7 } & Quick Ratio & 1.20 & 1.29 & 1.35 & 1.58 & 1.24 \\
\hline \multirow{2}{*}{ Vale SA Brazilian } & Current Ratio & 1.47 & 2.01 & 1.45 & 1.67 & 1.23 \\
\cline { 2 - 7 } & Quick Ratio. & 1.13 & 1.71 & 1.15 & 1.18 & 0.92 \\
\hline
\end{tabular}

- macroeconomic - economic situation, fiscal and monetary policy, degree of financial market development, currency policy, labour costs, purchase prices of production factors. Macroeconomic factors depend on the phenomena and processes occurring across the entire economy.

- $\quad$ sectoral - the specificity of the industry, level of industry development and modernity, level of industry risk, prospects of industry development.

Another criterion yet in the classification of factors affecting liquidity is the type of such factors. In this classification, factors are divided into those that are dependent on and those that are independent of the company (Wędzki 2003, p. 73). Factors dependent on the company involve the production technology used by the company, type of industry, management method and financial strategy. They all affect all components of net working capital. However, some components of this type of capital are affected by such determinants as cash flow volatility, the rate of profitability of sales, and the current expected rate of return on operating assets. Factors independent of the company affect all or certain components of the working capital and include the current and expected economic situation, the tax rates and other levies charged to the company, the level of interest rates affecting the cost of capital, the availability of capital from banks and the capital market, the degree of information asymmetry, the sector-specific rate of return on investment. In companies, there exists a strong correlation between factors dependent on the company and those that are independent of it, hence it is practically impossible to determine the impact of a specific factor on the company's liquidity. The company's management board must be knowledgeable about the determinants of financial liquidity, observe the company's economic, legal and social environment and react in a timely manner so as not to lose short-term financial equilibrium.

The liquidity level in mining companies is influenced by both external and internal factors arising from management's decisions. The former includes the economic situation and competition on the coal market, coal prices on exchanges, the rate of transformation from coal to other energy carriers, interest rates and exchange rates. Internal factors, on the other hand, are related to the rate of conversion of individual components of current assets to cash. The greater the share of highly liquid assets in current assets and the longer the payment time for current liabilities, the better the liquidity. The liquidity level in mining companies is undoubtedly influenced by the size of the company, the stage of its life cycle, the specificity of industry processes, the arrangement of logistical chains supporting processes from mining to marketing to further processing.

A good knowledge of liquidity determinants facilitates the management of the company's finances and is important in all economic conditions. It is crucial in times of economic downturns. Economic downturns verify companies' ability to survive in a competitive market. When one company loses liquidity, it sends ripples far and wide, causing payment problems in other entities and contributes to payment gridlocks in the economy. When demand declines during an economic slowdown and this is combined with payment gridlocks, it often means that maintenance of liquidity at all costs becomes the company's management's most important goal, and the adjacent costs are overlooked. Increasing shareholder value becomes a secondary consideration.

\section{Research Methods}

Twelve global mining companies listed on several stock exchanges were studied. These concerns can be divided into two groups. The first consists of entities with diversified mining activities and includes the British concern Anglo American, global concern BHP Group, Australia's Rio Tinto, Brazil's company Vale SA and the Russian corporation Mechel. In addition to coal, they also extract other raw materials located in the area for which the concern has obtained a mining license. The British Anglo-American prospects for copper, zinc, nick$\mathrm{el}$, iron ore and diamonds. The BHP Group explores, produces and processes minerals such as coal, copper and iron ore as well as oil and gas. The copper segment is focused on the extraction of copper, silver, lead, zinc, molybdenum, uranium and gold. The coal segment is centred around the extraction of coking and thermal coal. The Anglo-Australian company Rio Tinto focuses on extracting various types of minerals. The Brazilian mining concern Vale S.A. is the largest producer of iron ore and nickel in the world. It also produces manganese, ferroalloys, copper, bauxite, potassium and cobalt. Russia's global coal and metallurgical corporation Mechel produces coal, iron ore, steel, rolled products, ferro-alloys, heat and electricity. Such a diversified range of operations smoothens 
Tab. 2. The cash cycle in mining companies pursuing diversified activities, 2015-2019. Source: own calculations based on Ratios - Key Metrics retrieved from a Reuters database

Tab. 2. Cykl konwersji gotówki w spółkach wydobywczych o zdywersyfikowanej działalności w latach 2015 -2019. Źródło: opracowanie własne na podstawie Ratios - Key Metrics zaczerpniętych z bazy Reuters

\begin{tabular}{|l|l|r|r|r|r|r|}
\hline Company & Ratio & $\mathbf{2 0 1 5}$ & $\mathbf{2 0 1 6}$ & $\mathbf{2 0 1 7}$ & $\mathbf{2 0 1 8}$ & $\mathbf{2 0 1 9}$ \\
\hline Anglo American PLC & Avg. Invent. Days & 103.5 & 92.4 & 97.6 & 97.8 & 101.9 \\
\cline { 2 - 6 } & Avg. A/R Days & 40.8 & 37.7 & 31.3 & 27.1 & 26.0 \\
\cline { 2 - 6 } & Avg. A/R Days & 41.8 & 39.3 & 46.8 & 50.4 & 53.2 \\
\cline { 2 - 6 } & Avg. A/R Days & 102.5 & 90.8 & 82.1 & 74.5 & 74.7 \\
\hline BHP Group PLC & Avg. Invent. Days & 128.3 & 127.5 & 108.2 & 103.5 & 111.0 \\
\cline { 2 - 6 } & Avg. A/R Days & 55.7 & 34.6 & 26.4 & 28.0 & 31.2 \\
\cline { 2 - 6 } & Avg. A/R Days & 170.7 & 196.9 & 167.8 & 172.9 & 174.6 \\
\cline { 2 - 6 } & Avg. A/R Days & 13.5 & $(34.8)$ & $(33.1)$ & $(41.3)$ & $(32.3)$ \\
\hline Mechel PAO & Avg. Invent. Days & 86.5 & 88.1 & 83.6 & 83.8 & 77.3 \\
\cline { 2 - 6 } & Avg. A/R Days & 32.4 & 28.1 & 27.5 & 25.6 & 26.2 \\
\cline { 2 - 6 } & Avg. A/P Days & 63.7 & 59.6 & 46.0 & 44.6 & 41.9 \\
\cline { 2 - 6 } & Cash Cycle Days & 55.1 & 56.6 & 65.1 & 64.9 & 61.6 \\
\hline Rio Tinto PLC & Avg. Invent. Days & 65.1 & 60.2 & 59.7 & 63.7 & 64.8 \\
\cline { 2 - 6 } & Avg. A/R Days & 31.1 & 30.3 & 30.1 & 28.7 & 35.4 \\
\cline { 2 - 6 } & Avg. A/P Days & 46.2 & 54.7 & 57.3 & 60.1 & 58.2 \\
\cline { 2 - 6 } & Cash Cycle Days & 50.0 & 35.8 & 32.5 & 32.4 & 32.0 \\
\hline \multirow{4}{*}{ Vale SA Brazilian } & Avg. Invent. Days & 66.5 & 48.1 & 42.5 & 43.7 & 44.3 \\
\cline { 2 - 6 } & Avg. A/R Days & 39.6 & 24.7 & 18.1 & 17.1 & 18.6 \\
\cline { 2 - 6 } & Avg. A/P Days & 42.5 & 31.6 & 30.9 & 21.9 & 17.9 \\
\cline { 2 - 6 } & Cash Cycle Days & 63.7 & 41.2 & 29.7 & 38.9 & 45.0 \\
\hline
\end{tabular}

Avg. Inventory Days - Average Inventory Days

Avg. A/R Days - Average Accounts Receivable Days

Avg. A/P Days - Average Accounts Payable Days

Cash Cycle (Days)

financial results, as short business cycles do not occur simultaneously across all sectors. Losses in one area are compensated for by profits from other activities.

The second group consists of entities is focused on the coal segment. The largest players include the American companies Arch Resources and Peabody, the Indian company Coal India, the Australian company Whitehaven Coal Ltd. and the Russian company Raspadskaya. The activity of Polish companies LWB SA and JSW SA is focused only on coal mining, processing and transport. LWB SA has a logistical link with a power plant. JSW SA, on the other hand, focuses mainly on the extraction of coking coal.

To assess mining companies' liquidity, use was made of static liquidity ratios, and Days Inventory Outstanding, Accounts Receivable Days, Accounts Payable Days and the Cash Cycle. Their values were extracted from a Reuters database. The inventory cycle was determined as the ratio of the inventory balance at year end and the cost of goods sold. The fact that this cycle calculates production costs rather than sales revenues eliminates its large fluctuations caused by changes in coal prices and sales revenues. The Accounts Receivable Days is the ratio of accounts receivable to sales revenues, and the Accounts Payable Days is the ratio of accounts payable to the cost of goods sold. The cash cycle is Accounts Receivable Days plus Days Inventory Outstanding less Accounts Payable Days.

\section{Liquidity Levels in Companies Surveyed}

The static liquidity ratios in mining companies with diversified activities are presented in Table 1.

The values of the liquidity ratios are high and, in some years, higher than the normative standards recommended for these ratios. The values depend on the financial policy around inventories and accounts receivable, terms of payment for deliveries, which is influenced by external factors, including primarily the economic situation and the prices of raw materials. Mechel's ratios are far removed from the rational level. The company reports a high level of unsettled losses from previous periods and has negative equity. Its current liabilities are used to finance operating activities and non-current assets.

A more accurate picture of liquidity than that afforded by static liquidity ratios is painted by the cash cycle, which determines how quickly the company realises cash from inventories and accounts receivable and at what time it settles its maturing accounts payable. The cash cycles of mining companies with diversified operations presented in Table 2 show that they keep large inventories of extracted raw materials. In 2019, in Anglo-American which extracts raw materials on all continents, the Days Inventory Outstanding exceeded 100 days. BHP Group, the world's largest mining concern, kept inventories for almost 4 months. These inventories facilitate the timely delivery of raw materials to many countries. In the three remaining companies, the level of inventories oscillated around 60-80 days. At Vale SA, the figure fell from 66 to 44 days.

The size of inventories does not depend merely on the type of extracted raw materials, but also on the type of transport used, distance to recipients, logistics systems and links with power plants. For example, the Brazilian mining concern Vale SA owns nine power plants and a large network of railways, ships and ports, which facilitates the transport of manufactured products. In the Russian coal and metallurgical corporation Mechel, all of the Group's companies operate within 
Tab. 3. Current ratio in companies focused on coal mining activities, 2015-2019. Source: own calculations based on Ratios - Key Metrics retrieved from a Reuters database

Tab. 3. Wskaźniki bieżącej płynności finansowej w spółkach skoncentrowanych na wydobyciu węgla w latach 2015-2019. Źródło: opracowanie własne na podstawie sprawozdań spółek węglowych oraz Ratios - Key Metrics zaczerpniętych z bazy Reuters

\begin{tabular}{|l|l|r|r|r|r|r|}
\hline Company & Ratio & $\mathbf{2 0 1 5}$ & $\mathbf{2 0 1 6}$ & $\mathbf{2 0 1 7}$ & $\mathbf{2 0 1 8}$ & $\mathbf{2 0 1 9}$ \\
\hline Arch Resources Inc. & Current Ratio & 0.21 & 2.81 & 2.49 & 2.67 & 2.27 \\
\cline { 2 - 7 } & Quick Ratio & 0.17 & 2.45 & 2.10 & 2.29 & 1.85 \\
\hline \multirow{2}{*}{ Coal India Ltd. } & Current Ratio & 2.31 & 1.59 & 1.37 & 1.51 & 1.72 \\
\cline { 2 - 7 } & Quick Ratio & 2.04 & 1.37 & 1.23 & 1.39 & 1.59 \\
\hline \multirow{2}{*}{ SSW SA } & Current Ratio & 0.37 & 1.02 & 1.37 & 0.95 & 0.96 \\
\cline { 2 - 7 } & Quick Ratio & 0.25 & 0.88 & 1.57 & 0.77 & 0.64 \\
\hline \multirow{2}{*}{ LWB SA } & Current Ratio & 1.59 & 1.16 & 0.98 & 1.07 & 1.98 \\
\cline { 2 - 7 } & Quick Ratio & 1.33 & 1.07 & 0.90 & 1.05 & 1.71 \\
\hline Peabody Energy Corp. & Current Ratio & 0.18 & 2.07 & 1.76 & 1.85 & 1.65 \\
\cline { 2 - 7 } & Quick Ratio & 0.14 & 1.86 & 1.53 & 1.58 & 1.31 \\
\hline \multirow{2}{*}{ Raspadskaya PAO } & Current Ratio & 1.12 & 0.69 & 0.99 & 1.60 & 3.37 \\
\cline { 2 - 7 } & Quick Ratio & 1.03 & 0.65 & 0.65 & 1.48 & 3.11 \\
\hline Whitehaven Coal Ltd. & Current Ratio & 1.22 & 1.30 & 1.40 & 0.94 & 1.25 \\
\cline { 2 - 7 } & Quick Ratio & 0.84 & 0.91 & 0.94 & 0.59 & 0.81 \\
\hline
\end{tabular}

Tab. 3. Current ratio in companies focused on coal mining activities, 2015-2019. Source: own calculations based on Ratios - Key Metrics retrieved from a Reuters database

Tab. 3. Wskaźniki bieżącej płynności finansowej w spółkach skoncentrowanych na wydobyciu węgla w latach 2015-2019. Źródło: opracowanie własne na podstawie sprawozdań spółek węglowych oraz Ratios - Key Metrics zaczerpniętych z bazy Reuters

\begin{tabular}{|c|c|c|c|c|}
\hline Company & Ratio & 2015 & 2016 & 2017 \\
\hline \multirow[t]{4}{*}{ Arch Resources Inc. } & Avg. Invent. Days & 32.1 & 32.8 & 24.1 \\
\hline & Avg. A/R Days & 26.2 & 31.5 & 32.6 \\
\hline & Avg. A/P Days & 25.6 & 23.7 & 22.5 \\
\hline & Cash Cycle Days & 32.7 & 40.6 & $33 . \overline{2}$ \\
\hline \multirow[t]{4}{*}{ Coal India Ltd. } & Avg. Invent. Days & 48.7 & 52.9 & 44.5 \\
\hline & Avg. A/R Days & 87.7 & 104.0 & $113 .{ }^{2}$ \\
\hline & Avg. A/P Days & 20.4 & 21.5 & 30.5 \\
\hline & Cash Cycle Days & 115.0 & 135.4 & 127.4 \\
\hline \multirow[t]{4}{*}{ JSW SA } & Avg. Invent. Days & 27.0 & 27.8 & 27.3 \\
\hline & Avg. A/R Days & 41.1 & 40.9 & $35 . \varepsilon$ \\
\hline & Avg. A/P Days & 113.7 & 135.4 & 131.4 \\
\hline & Cash Cycle Days & $(45.6)$ & $(66.8)$ & $(68.3$ \\
\hline \multirow[t]{4}{*}{ LWB SA } & Avg. Invent. Days & 20.8 & 22.4 & 28.6 \\
\hline & Avg. A/R Days & 55.7 & 53.9 & 50.1 \\
\hline & Avg. A/P Days & 63.9 & 74.9 & 134.5 \\
\hline & Cash Cycle Days & 12.7 & 1.3 & $(56.0$ \\
\hline \multirow[t]{4}{*}{ Peabody Ener. Corp. } & Avg. Invent. Days & 27.9 & 22.8 & 22.5 \\
\hline & Avg. A/R Days & 25.8 & 27.2 & 33.6 \\
\hline & Avg. A/P Days & 31.0 & 27.7 & 30.7 \\
\hline & Cash Cycle Days & 22.7 & 22.3 & 25.4 \\
\hline \multirow[t]{4}{*}{ Raspadskaya PAO } & Avg. Invent. Days & 38.4 & 35.1 & 36.7 \\
\hline & Avg. A/R Days & 111.5 & 285.4 & $225 . c$ \\
\hline & Avg. A/P Days & 28.2 & 46.4 & 46.5 \\
\hline & Cash Cycle Days & 121.8 & 274.2 & 205.1 \\
\hline Whitehaven Coal Ltd. & Avg. Invent. Days & 66.5 & 48.1 & 42.5 \\
\hline
\end{tabular}

a single production chain - from raw materials to high added value products. The BHP Group has a negative cash cycle resulting from much longer payment terms for amounts payable than amounts receivable.

Table 3 shows the liquidity ratios of companies extracting primarily coal. The diversification of their activities is the result of either coal processing processes, coal's use in heating or auxiliary processes connected with the mining processes.

All the companies surveyed reported high liquidity ratios and these fall within the normative range. In 2019, many companies saw their liquidity ratios rise. JSW SA'S ratios were the lowest among the companies surveyed. It does not mean, however, that the company does not settle its liabilities on time. The level of ratios depends on the one hand on the method of recognition of current assets, and on the other hand, on the financial policy regarding inventories and accounts receivable. Inventories are shown in the balance sheet at the cost of production. The cash realised from their sale is much higher than this cost because the price of coal in normal economic conditions includes, in addition to production 
costs, also cost of goods sold, general and administrative expenses and profit. In line with the principle of conservatism, in the balance sheet, accounts receivable are recognised at their net value, i.e. after adjusting entries related to the risk of their non-realisation of cash. Additionally, current assets do not reflect the fact that the company constantly generates funds through day-to-day operations, and these can be used to pay off maturing current liabilities. The fact that companies can settle their liabilities out of available factoring and credit lines is also disregarded. These are not reported in the balance sheet until the company has used them. They can constitute a potential liquidity cushion, as can the difference between the book and market value of inventories and accounts receivable.

The specificity of mining processes necessitates the use of the cash cycle consisting of partial Days Inventory Outstanding, Accounts Receivable Days and Accounts Payable Days to assess financial liquidity. Mining companies keep inventories of raw materials to ensure that they can continue to supply customers. Polish companies maintain smaller coal inventories than their global counterparts. JSW's inventories on average cover 30 days, as do to Peabody's, which supplies coal to the US domestic market. LWB SA has only 20 days of coal in stock. Coal exporting companies' inventories must be even larger. (Table 4).

Coal companies have lower levels of inventories of raw materials than companies with diversified mining activities. Characteristically, Polish coal companies report a negative cash cycle resulting from a longer deferral of settlement of accounts payable, which exceeds the time needed to realise accounts receivable. India Coal and Raspadskaya report exceptionally long cash cycles. In Raspadskaya in 2016, the cycle was 274 days on account of very long Accounts Receivable Days. In 2016, the company waited 285 days for settlement of debts by buyers. Coal India has a similarly long waiting peri- od. On the other hand, very long waiting periods for settlement of accounts payable occur in BHP Group companies and JSW SA. In other coal companies, they average 30-60 days.

\section{Conclusions}

Liquidity maintenance underpins efficient company management. Rational liquidity management decisions depend on whether managements have or do not have reliable information at their disposal. In the mining industry, the commonly used liquidity ratios are not enough to guarantee rational decisions about liquidity and can only serve to provide certain information. The specificity of mining manifests itself, inter alia, in high levels of inventories of extracted raw materials. An increase in inventories causes the current ratio to increase, and its level above the accepted normative values is often construed as excess liquidity. Meanwhile, an increase in liquidity ratios resulting from an increase in inventories indicates deteriorating liquidity. Mining companies, especially those which pursue diverse activities extracting various resources, have a high current ratio. These companies maintain a higher level of inventories than those entities which are focused only on coal mining. Moreover, inventory levels depend on the distance to markets and the need to ensure continuity of supplies. Lower inventories in coal companies are often due to logistical links with coal-consuming power plants. The resulting lower liquidity ratios are not indicative of lower liquidity.

Static measurement of liquidity is insufficient to properly monitor companies' ability to settle their debt in a timely manner. Such measurement is supplemented with data on the cash cycle and its constituents - Days Inventory Outstanding, Accounts Receivable Days and Accounts Payable Days. Accounts Receivable Days and Accounts Payable Days illustrate the company's trade credit policy, which plays a key role in liquidity maintenance. 


\section{Literatura - References}

1. Ashraf Ch. K. (2012). The Relationship between Working Capital Efficiency and Profitability, The Journal of Accounting and Management 2012, Issue, pp.21-45.

2. Bond C. J. (1993). Credit Management Handbook, A Complete Guide to Credit and Accounts Receivable Operations, McGraw-Hill, Inc., New York.

3. Gowthami R. (2012). A Study on Liquidity Performance of Top Performing Manufacturing Industries, Journal of Finance, Accounting and Management, 3(1), pp. 45-60, January.

4. Grabowska M. (2012). Zarządzanie płynnością finansową przedsiębiorstw, CeDeWu, Warszawa.

5. Kieso D.E., Weygandt J.J. (1992). Intermediate Accounting, John Wiley \& Sons Inc., New York.

6. Kirkham R. (2012). Liquidity Analysis Using Cash Flow Ratios and Traditional Ratios: The Telecommunications Sector in Australia, Journal of New Business Ideas \& Trends, 10(1), pp. 1-13.

7. Kwiecień A. (2015). Zarządzanie płynnością jako sposób na poprawę efektywności w zarządzaniu finansami, Zeszyty Naukowe Uniwersytetu Szczecińskiego, nr 854, Finanse, Rynki Finansowe, Ubezpieczenia, nr 73, s.39-46.

8. Michalski G. (2005). Płynność finansowa w małych i średnich przedsiębiorstwach, WN PWN Warszawa 2005.

9. Ostaszewski J, Cicirko T. (2006). Finanse spółki akcyjnej, Difin, Warszawa.

10. Rogowski W., Lipski A. (2014). Płynność finansowa - wybrane zagadnienia, w: Płynność finansowa przedsiębiorstw w Polsce. Uwarunkowania, zarządzanie płynnością, ryzyko (red. J. Grzywacz, Oficyna Wydawnicza SGH, Warszawa.

11. Sierpińska M., Jachna T. (2009). Ocena przedsiębiorstwa według standardów światowych, WN PWN, Warszawa.

12. Szczepaniak P. (2014). Kapitał obrotowy w sektorach niefinansowych w Polsce w latach 2009 -2012, Zeszyty Naukowe Wyższej Szkoły Bankowej we Wrocławiu, nr 3(41), s.171 -182.

13. Wędzki D. (2003). Strategie płynności finansowej przedsiębiorstwa. Przepływy pieniężne a wartość dla właścicieli, Oficyna Ekonomiczna, Kraków.

14. Zawadzka D. (2009). Empiryczna ocena płynności finansowej w mikro-, małych przedsiębiorstw- ujęcie porównawcze, Zeszyty Naukowe Uniwersytetu Szczecińskiego, Ekonomiczne Problemy Usług, nr 34, s. 603-610

Problemy pomiaru płynności finansowej spółek górniczych

Umiejętność sterowania płynnością finansową ma znaczenie w każdych warunkach gospodarczych. Szczególnie ważna staje się w warunkach dekoniunktury. Jest ona uwarunkowana posiadaniem wiarygodnych informacji o poziomie płynności finansowej. Takich informacji nie zapewniają statyczne wskaźniki płynności finansowej. Ich wysoki poziom wynika z utrzymywanych wysokich stanów zapasów wydobywanych surowców i nie wskazuje na nadpłynność finansową. Dodatkowych informacji dostarczają cykle konwersji gotówki i składające się na nie cykle zapasów, należności i zobowiązań krótkoterminowych. Długie cykle konwersji gotówki wskazują na krótszy czas odroczenia płatności zobowiązań wobec dostawców i niższy poziom płynności finansowej. Dla zachowania płynności finansowej spółki musza utrzymywać na kontach wyższe stany środków pieniężnych. Cykle krótkie moga natomiast wynikać $z$ przeterminowania płatności faktur co znajduje odzwierciedlenie w długich cyklach zobowiazań krótkoterminowych. Niektóre spółki węglowe mają bardzo długie cykle zobowiązań i ujemne cykle konwersji gotówki. Oznacza to że część aktywów trwałych finansuja zobowiązaniami krótkoterminowymi.

Słowa kluczowe: płynność, wskaźniki płynności, cykl gotówkowy 